\title{
PEMODELAN PENYEBARAN KASUS DEMAM BERDARAH DENGUE (DBD) DI KOTA DENPASAR DENGAN METODE SPATIAL AUTOREGRESSIVE (SAR)
}

\author{
Ni Made Surya Jayanti ${ }^{1 \S}$, I Wayan Sumarjaya ${ }^{2 \S}$, Made Susilawati ${ }^{3}$ \\ ${ }^{1}$ Jurusan Matematika, FMIPA - Universitas Udayana [Email: suryajayanti88@gmail.com] \\ ${ }^{2}$ Jurusan Matematika, FMIPA - Universitas Udayana [Email: sumarjaya@unud.ac.id] \\ ${ }^{3}$ Jurusan Matematika, FMIPA - Universitas Udayana [Email: madesusilawati@unud.ac.id] \\ ${ }^{\S}$ Corresponding Author
}

\begin{abstract}
One of spatial regression model is Spatial Autoregressive (SAR), which assumes that the autoregressive process only on the dependent variable only by considering the spatial effects. There are two aspects of spatial effects, that is spatial dependence and spatial heterogeneity. One of the problems which considers spatial effect is the spread of Dengue Hemorrhagic Fever (DHF). Denpasar City is an endemic DHF disease because there have been DHF cases in three consecutive years or more. The purpose of this research is to estimate the spread of DHF in Denpasar City along with the factors that affect it. The results show that the factors that influence the spread of DHF are neighborhood, area and the role of Jumantik at the every village in Denpasar City.
\end{abstract}

Keywords: DHF, Spatial Effects, Spatial Autoregressive (SAR)

\section{PENDAHULUAN}

Analisis regresi merupakan salah satu analisis yang bertujuan untuk mencari pola hubungan antara variabel dependen dengan variabel independen. Salah satu model dalam analisis regresi yaitu model regresi linear. Model regresi linear juga dapat dikembangkan dengan mempertimbangkan efek ruang atau spasial yang disebut dengan model regresi spasial.

Pengembangan pada model regresi linear karena adanya pengaruh spasial pada data yang dianalisis. Sehingga, jika terdapat data dengan efek spasial maka analisis yang digunakan adalah analisis regresi spasial. Dalam Anselin (1988) Tobler mengemukakan bahwa hukum pertama tentang geografi menyatakan segala sesuatu saling berhubungan satu dengan yang lainnya, tetapi sesuatu yang dekat mempunyai pengaruh lebih besar daripada yang jauh. Hukum tersebut merupakan dasar pengkajian permasalahan berdasarkan efek spasial atau metode spasial.

Pada pemodelan spasial, disusun sebuah matriks pembobot spasial untuk mengetahui hubungan spasial yang terjadi antara daerah satu dengan daerah lainnya. Matriks pembobot spasial diperoleh dengan memperhatikan persinggungan antara daerah satu dengan daerah lainnya sesuai dengan peta pembagian wilayah. Dalam model regresi spasial secara resmi ditetapkan dua aspek dari efek spasial yaitu adanya dependensi (kebergantungan) spasial dan heterogenitas (keragaman) spasial, yang mendapat perhatian khusus dari sudut pandang metodologis (Anselin, 1988).

Salah satu model regresi spasial adalah Spatial Autoregressive (SAR) yang mengasumsikan bahwa proses autoregresif hanya pada variabel dependen saja (Anselin, 1988). Proses autoregresif merupakan proses yang menggambarkan bahwa variabel dependen dipengaruhi oleh variabel dependen itu sendiri. Regresi spasial ini banyak digunakan pada bidang seperti kesehatan, sosial, dan klimatologi (A'yunin dan Sutijo, 2011).

Salah satu permasalahan kesehatan di Indonesia adalah penyakit Demam Berdarah Dengue (DBD). Kementerian Kesehatan RI 
(2015) menyatakan bahwa penyakit DBD dapat muncul sepanjang tahun dan dapat menyerang seluruh kelompok umur, penyakit ini berkaitan dengan kondisi lingkungan dan perilaku masyarakat.

Berdasarkan data dari Dinas Kesehatan Provinsi Bali (2015), penyakit DBD termasuk dalam pola sepuluh besar penyakit pada pasien rawat inap di RSUD di Provinsi Bali tahun 2014 dengan jumlah kasus tertinggi yaitu sebanyak 6.504 kasus. Pada tahun 2014 jumlah kasus DBD terbanyak terdapat di Kota Denpasar yaitu sebanyak 1.837 kasus, Kabupaten Gianyar sebanyak 1.785 kasus, Kabupaten Badung sebanyak 1.770 kasus, dan Kabupaten Buleleng sebanyak 1.721 kasus. Kota Denpasar merupakan daerah endemis penyakit DBD karena ditemukan kasus DBD selama tiga tahun berturut-turut atau lebih. Berdasarkan data dari Dinas Kesehatan Kota Denpasar (2015), jumlah kasus DBD di Kota Denpasar selama lima tahun berturut-turut sebagai berikut: 2.190 kasus (2009),4.431 kasus (2010), 981 kasus (2011), 1.009 kasus (2012), dan 1.766 kasus (2013).

Virus DBD diduga menyebar secara cepat dari satu daerah ke daerah lainnya yang berdekatan, sehingga kemungkinan kedekatan daerah mempengaruhi penyebaran kasus DBD. Daerah dengan kepadatan penduduk yang tinggi kemungkinan menjadi salah satu faktor risiko penyebaran kasus DBD. Dengan demikian perlu dikaji pola penyebaran kasus DBD berdasarkan efek spasial pada daerah dengan kepadatan penduduk yang tinggi. Oleh karena itu, pada penelitian ini menggunakan metode Spatial Autoregressive (SAR) karena dinilai dapat mewakili permasalahan yang berpengaruh terhadap penyebaran kasus DBD berdasarkan efek spasial, serta untuk menganalisis faktorfaktor yang berpengaruh terhadap penyebaran kasus DBD di Kota Denpasar.

Tujuan yang ingin dicapai dalam penelitian ini adalah sebagai berikut: (1) Menduga model regresi penyebaran kasus DBD di Kota Denpasar dengan metode SAR, (2) Mendeskripsikan faktor-faktor yang memengaruhi penyebaran kasus DBD di Kota Denpasar dengan metode SAR.

\section{KAJIAN PUSTAKA}

\subsection{Regresi Spasial}

Regresi spasial merupakan salah satu metode statistika yang digunakan untuk mengetahui hubungan antara variabel dependen dengan variabel independen dengan mempertimbangkan pengaruh efek spasial antardaerah (Anselin, 1988). Pengaruh efek spasial tersebut disajikan dalam bentuk koordinat daerah atau pembobotan. Model regresi spasial dinyatakan dalam persamaan berikut (Anselin, 1988, p.34):

dengan

$$
y=\rho W_{1} y+X \beta+\varepsilon
$$$$
\varepsilon=\lambda W_{2} \varepsilon+\mu
$$

dan

atau

$$
\mu \sim N(0, \Omega)
$$

$$
y=\rho W_{1} y+X \beta+\lambda W_{2} \varepsilon+\mu
$$

keterangan:

$y:$ Vektor variabel dependen

$X:$ Matriks variabel independen

$\beta$ : Vektor parameter koefisien regresi

$\rho$ : Koefisien spasial beda kala (lag) variabel dependen

$\lambda$ : Koefisien spasial beda kala (lag) pada error

$\varepsilon$ : Vektor error pada persamaan (1)

$\mu$ : Vektor error pada persamaan (2)

$W_{1}, W_{2}$ : Matriks pembobot spasial

Persamaan (1) dan (2) untuk matriks $W_{1}$ dan $W_{2}$ merupakan pembobot yang menunjukkan hubungan persinggungan antardaerah. Untuk $i=j$ nilai $w_{i j}=0$ dan untuk $i \neq j$ nilai $w_{i j}=w_{j i}$, sehingga diagonal utama dari matriks pembobot spasial bernilai nol, dengan $i=1,2, \ldots, n$ dan $j=1,2, \ldots, n$ yang menunjukkan banyaknya pengamatan.

\subsection{Matriks Pembobot Spasial}

Hal yang sangat penting dalam analisis spasial adalah adanya pembobot atau yang sering disebut sebagai matriks pembobot spasial. Matriks pembobot spasial digunakan untuk menentukan bobot antardaerah yang diamati berdasarkan hubungan ketetanggaan antardaerah. Menurut Anselin (1988), struktur yang mendasari ketetanggaan diungkapkan dengan bobot 0 dan 1 . 
Lee dan Wong (2001) menyebutkan bahwa matriks persinggungan sebagai matriks penghubung dengan semua elemen diagonal matriksnya bernilai 0 , karena diasumsikan bahwa suatu daerah tidak berdekatan dengan dirinya sendiri. Pada dasarnya matriks persinggungan menggambarkan hubungan timbal balik dari hubungan spasial, sehingga matriks segitiga atas sepanjang diagonal utama merupakan cermin dari segitiga bawah. Baris dalam matriks persinggungan menunjukkan suatu daerah berhubungan spasial dengan daerah lain, sehingga jumlah nilai pada baris ke-i merupakan jumlah tetangga yang dimiliki oleh daerah ke- $i$.

Gambar 1 merupakan ilustrasi persinggungan mengenai perhitungan matriks pembobot spasial dengan lima daerah sebagai amatannya. Sesuai dengan persinggungan queen didapatkan elemen-elemen dari matriks pembobot spasial yaitu: $w_{12}=w_{21}=1, w_{23}=$ $w_{32}=1, w_{34}=w_{43}=1, w_{35}=w_{53}=$ $1, w_{45}=w_{54}=1$ dan yang lain sama dengan nol. Matriks pembobot spasial $W$ ini memiliki ukuran matriks $5 \times 5$.

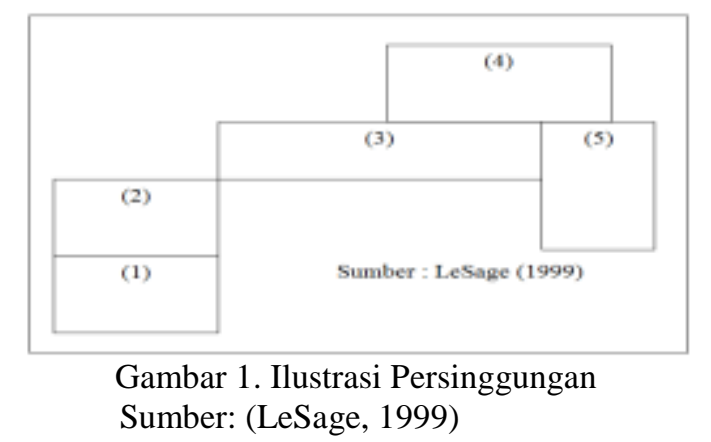

Matriks pembobot spasial dengan persinggungan queen yang dapat terbentuk dari Gambar 1 adalah sebagai berikut:

$$
W_{\text {Queen }}=\left[\begin{array}{lllll}
0 & 1 & 0 & 0 & 0 \\
1 & 0 & 1 & 0 & 0 \\
0 & 1 & 0 & 1 & 1 \\
0 & 0 & 1 & 0 & 1 \\
0 & 0 & 1 & 1 & 0
\end{array}\right] .
$$

\subsection{Spatial Autoregressive (SAR)}

Menurut Anselin (1988), model Spatial Autoregressive (SAR) adalah model yang mengombinasikan model regresi linear dengan spasial beda kala (lag) pada variabel dependen dengan menggunakan data cross section. Model SAR terbentuk apabila $\lambda=0$ (dilihat dari persamaan (1) dan (2)), sehingga model ini mengasumsikan bahwa proses autoregresif hanya pada variabel dependen.

Model umum SAR ditunjukan oleh persamaan sebagai berikut (Anselin, 1988, p.35):

$$
\begin{gathered}
y=\rho W_{1} y+X \beta+\varepsilon \\
\varepsilon \sim N\left(0, \sigma^{2} I\right) .
\end{gathered}
$$

$$
\varepsilon=\left(I-\rho W_{1}\right) y-X \beta \text {. }
$$

\subsection{Pendugaan Parameter SAR}

Menurut Anselin (1988), untuk mengetahui model SAR ini konsisten, maka dikembangkan model pendugaan parameter dengan Maximum Likelihood Estimation (MLE). Langkah pertama adalah dengan membentuk fungsi likelihood dari persamaan (4). Pembentukan fungsi

$L\left(\varepsilon ; \sigma^{2}\right)=\left(\frac{1}{2 \pi \sigma^{2}}\right)^{n / 2} \exp \left[-\frac{1}{2 \sigma^{2}}\left(\varepsilon^{\prime} \varepsilon\right)\right]$.

likelihood tersebut dilakukan melalui error $(\varepsilon)$ :

Mengingat $\quad \varepsilon \sim N\left(0, \sigma^{2} I\right)$ maka $\varepsilon$ dapat dinyatakan dalam fungsi densitas $f\left(\varepsilon_{i}\right)$ dengan

$$
f\left(\varepsilon_{i}\right)=\frac{1}{\left(2 \pi \sigma^{2}\right)^{1 / 2}} \exp \left[-\frac{1}{2 \sigma^{2}}\left(\varepsilon_{i}\right)^{2}\right]
$$

Selanjutnya, fungsi likelihood $L$ dinyatakan sebagai fungsi densitas bersama vektor $\varepsilon$ yaitu:

Berdasarkan fungsi likelihood pada persamaan (7), dapat dinyatakan sebagai fungsi dari $\rho, \beta, \sigma^{2}$ dengan:

$$
\begin{aligned}
L\left(\rho, \beta, \sigma^{2} \mid y\right) & =\left(\frac{1}{2 \pi \sigma^{2}}\right)^{n / 2}\left|I-\rho W_{1}\right| \times \\
& \exp \left(-\frac{1}{2 \sigma^{2}}\left\{\left[\left(I-\rho W_{1}\right) y-\right.\right.\right. \\
& \left.\left.X \beta]^{\prime}\left[\left(I-\rho W_{1}\right) y-X \beta\right]\right\}\right) .
\end{aligned}
$$


Operasi logaritma natural (ln) likelihood dinyatakan pada persamaan berikut:

$$
\begin{aligned}
\ln (L)= & -\frac{n}{2} \ln (2 \pi)-\frac{n}{2} \ln \left(\sigma^{2}\right)+ \\
& \ln \left|I-\rho W_{1}\right|-\frac{1}{2 \sigma^{2}}\{[(I- \\
& \left.\left.\rho W_{1}\right) y-X \beta\right]^{\prime}\left[\left(I-\rho W_{1}\right) y-\right. \\
& X \beta]\} .
\end{aligned}
$$

Sehingga dari persamaan (9) diperoleh pendugaan parameter $\rho, \beta$, dan $\sigma^{2}$.

\section{1) Pendugaan Parameter $\rho$}

Fungsi ln likelihood untuk menduga $\rho$ adalah sebagai berikut:

$$
\begin{gathered}
\ln [L(\rho)]=c-\frac{n}{2} \ln \left[( e _ { 0 } - \rho e _ { L } ) ^ { \prime } \left(e_{0}-\right.\right. \\
\left.\left.\rho e_{L}\right)\right]+\ln \left|I-\rho W_{1}\right|
\end{gathered}
$$

dengan

$$
c=-\frac{n}{2} \ln (2 \pi)+\frac{n}{2} \ln (n)-\frac{n}{2} .
$$

Selanjutnya pendugaan parameter $\rho$ diperoleh dengan memaksimumkan persamaan (10). Pendugaan parameter $\rho$ tidak didapat secara langsung, namun dapat menggunakan teknik numerik dalam memaksimumkan persamaan (10).

\section{2) Pendugaan Parameter $\boldsymbol{\beta}$}

Penduga parameter $\beta$ diperoleh dengan memaksimumkan fungsi ln likelihood pada persamaan (9) yaitu dengan menurunkan persamaan tersebut terhadap $\beta$ dan menyamakannya dengan nol. Sehingga diperoleh bahwa pendugaan parameter $\beta$ adalah sebagai berikut:

$$
\hat{\beta}=\left(X^{\prime} X\right)^{-1} X^{\prime} y-\rho\left(X^{\prime} X\right)^{-1} X^{\prime} W_{1} y .
$$

\section{3) Pendugaan Parameter $\sigma^{2}$}

Penduga parameter $\sigma^{2}$ diperoleh dengan memaksimumkan fungsi $\ln$ likelihood pada persamaan (9) yaitu dengan menurunkan persamaan tersebut terhadap $\sigma^{2}$ dan menyamakannya dengan nol. Sehingga diperoleh bahwa pendugaan parameter $\sigma^{2}$ adalah sebagai berikut:

$$
\hat{\sigma}^{2}=\frac{\left[\left(I-\rho W_{1}\right) y-X \beta\right]^{\prime}\left[\left(I-\rho W_{1}\right) y-X \beta\right]}{n} .
$$

\subsection{Uji Efek Spasial}

Dalam model regresi spasial ditetapkan dua aspek dari efek spasial yaitu adanya kebergantungan spasial dan heterogenitas spasial. Untuk mengetahui adanya efek spasial pada data maka dilakukan metode pengujian.

\section{1) Uji Kebergantungan Spasial}

Uji untuk mengetahui kebergantungan spasial atau autokorelasi spasial antardaerah di dalam suatu model dengan menggunakan statistik Moran's I (Lee dan Wong, 2001). Hipotesis yang digunakan adalah:

$\mathrm{H}_{0}: \mathrm{I}=0$ (tidak ada kebergantungan spasial antardaerah),

$\mathrm{H}_{1}: \mathrm{I} \neq 0$ (ada kebergantungan spasial antardaerah).

Statistik uji disajikan dalam persamaan berikut (Lee dan Wong, 2001, p.82):

$$
Z_{\mathrm{I}}=\frac{\mathrm{I}-\mathrm{E}(\mathrm{I})}{\sqrt{V(\mathrm{I})}}
$$

dengan,

keterangan:

$x_{i}:$ data variabel amatanke- $i(i=1,2, \ldots, n)$

$x_{j}:$ data variabel amatan ke-j $(j=1,2, \ldots, n)$

$\bar{x}$ : rata-rata data

$\mathrm{I}=\frac{n \sum_{i=1}^{n} \sum_{j=1}^{n} w_{i j}\left(x_{i}-\bar{x}\right)\left(x_{j}-\bar{x}\right)}{W \sum_{i=1}^{n}\left(x_{i}-\bar{x}\right)^{2}}$

$E(\mathrm{I})=\mathrm{I}_{0}=-\frac{1}{n-1}$,

$V(\mathrm{I})=\frac{n^{2} S_{1}-n S_{2}+3 W^{2}}{W^{2}\left(n^{2}-1\right)}-[E(I)]^{2}$,

$W=\sum_{i=1}^{n} \sum_{j=1}^{n} w_{i j}$

$S_{1}=\frac{\sum_{i=1}^{n} \sum_{j=1}^{n}\left(w_{i j}+w_{j i}\right)^{2}}{2}$

$S_{2}=\sum_{i=1}^{n}\left(w_{i .}+w_{. i}\right)^{2}$,

$w_{i .}=\sum_{j=1}^{n} w_{i j}, w_{. i}=\sum_{j=1}^{n} w_{j i}$.

$V(\mathrm{I})$ : varians Moran's I

$E(I):$ nilai ekspektasi Moran's I 
Pengambilan keputusan dilakukan jika $\left|Z_{\mathrm{I}}\right|>Z_{\alpha / 2}$, maka $H_{0}$ ditolak.

Nilai dari indeks I adalah antara -1 dan 1. Jika $\mathrm{I}>\mathrm{I}_{0}$ maka data memiliki autokorelasi positif, jika $\mathrm{I}<\mathrm{I}_{0}$ maka data memiliki autokorelasi negatif. Pola pengelompokan dan penyebaran antardaerah dapat disajikan dengan Moran's Scatterplot pada Gambar 2. Moran's Scatterplot menunjukkan hubungan antara nilai amatan pada suatu daerah dengan nilai amatan dari daerah-daerah yang bertetanggaan dengan daerah yang bersangkutan.

Moran's Scatterplot tersebut terdiri atas empat kuadran, yaitu kuadran I, kuadran II, kuadran III, dan kuadran IV. Daerah-daerah yang banyak berada di kuadran I dan kuadran III cenderung memiliki autokorelasi positif, sedangkan daerah-daerah yang banyak berada di kuadran II dan kuadran IV cenderung memiliki autokorelasi negatif.

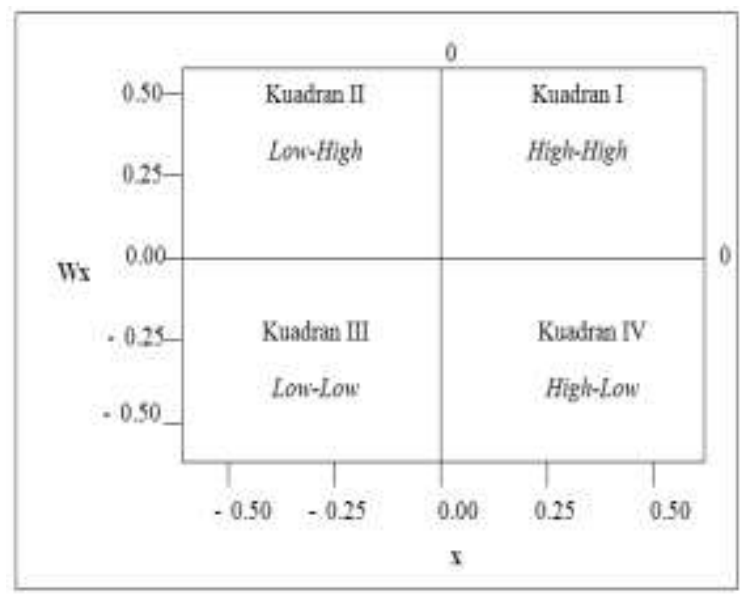

Gambar 2. Moran's Scatterplot

\section{2) Uji Heterogenitas Spasial}

Uji heterogenitas spasial digunakan untuk menunjukkan adanya keragaman antardaerah. Heterogenitas data secara spasial dapat diuji dengan menggunakan Breusch-Pagan Test (Anselin, 1988, p.70), yang mempunyai hipotesis sebagai berikut:

$$
\begin{aligned}
& \mathrm{H}_{0}: \sigma_{1}^{2}=\sigma_{2}^{2}=\cdots=\sigma_{n}^{2}=\sigma^{2} \quad \text { (tidak ada } \\
& \text { heterogenitas spasial), } \\
& \mathrm{H}_{1} \text { : minimal ada satu } \sigma_{\mathrm{i}}^{2} \neq \sigma^{2} \quad \text { (ada } \\
& \text { heterogenitas spasial), }
\end{aligned}
$$

$$
\mathrm{BP}=(1 / 2) f^{\prime} Z\left(Z^{\prime} Z\right)^{-1} Z^{\prime} f
$$

dengan elemen vektor $f$ adalah:

$$
f_{i}=\left(\frac{\varepsilon_{i}^{2}}{\sigma^{2}}-1\right)
$$

dengan

$\varepsilon_{i}$ : merupakan vektor residualuntuk amatan ke- $i$

$Z$ : merupakan matriks berukuran $n \times(k+1)$ yang berisi vektor yang sudah distandarkan $(z)$ untuk setiap amatan.

Pengambilan keputusan dilakukan jika BP $>\chi_{\alpha, k}^{2}$, maka $H_{0}$ ditolak.

\subsection{Pengujian Hipotesis Signifikasi Pendugaan Parameter}

Pengujian terhadap parameter model dilakukan untuk mengetahui peranan variabel independen dalam model. Pengujian hipotesis untuk signifikansi parameter pada penelitian ini menggunakan uji Wald. Rumus untuk uji Wald berdasarkan hipotesis adalah sebagai berikut(Anselin, 1988):

$\mathrm{H}_{0}: \hat{\rho}=0, \hat{\beta}_{j}=0$ (Parameter signifikan),

$\mathrm{H}_{1}: \hat{\rho}, \hat{\beta}_{j} \neq 0$ (Parameter tidak signifikan), statistik uji yang digunakan adalah pada persamaan(Anselin, 1988, p.68):

$$
\mathrm{W}=\left[\frac{\hat{\beta}_{j}^{2}}{\operatorname{var}\left(\hat{\beta}_{j}\right)}\right]
$$

dengan $\hat{\rho}$ menyatakan penduga parameter rho, $\hat{\beta}_{j}$ menyatakan penduga parameter ke- $j$, dan $\operatorname{var}\left(\hat{\beta}_{j}\right)$ menyatakan varians parameter ke-j. Kriteria pengambilan keputusan adalah mengikuti sebaran $\chi_{\alpha, 1}^{2} \cdot \mathrm{H}_{0}$ ditolak jika nilai $\mathrm{W}>\chi_{\alpha, 1}^{2}$.

\subsection{Pemilihan Model Terbaik}

Pemilihan model terbaik dilakukan untuk mendapatkan faktor yang paling mendukung penelitian. Ada beberapa kriteria dalam menentukan model terbaik. Kriteria pemilihan model terbaik yang digunakan dalam penelitian ini adalah Akaike's Information Criterion (AIC). AIC dirumuskan sebagai berikut (Anselin, 1988, p.246):

$$
A I C=-2 L+2 k
$$


dengan $L$ merupakan nilai maksimum loglikelihood, $k$ merupakan banyaknya parameter dalam model. Model yang dipilih berdasarkan kriteria AIC adalah model yang memiliki nilai AIC paling kecil.

\subsection{DBD dan Faktor Penyebarannya}

Beberapa faktor penyebaran penyakit DBD antara lain:

1. Kepadatan penduduk

Berdasarkan Dinas Kesehatan Provinsi Bali (2015), daerah yang memiliki jumlah penduduk yang besardengan kepadatan penduduk yang tinggi merupakan salah satu faktor risiko penyebaran penyakit DBD. Semakin padat penduduk, semakin mudah nyamuk Aedesaegypti menularkan virusnya dari satu orang ke orang lainnya.

2. Luas wilayah

Menurut Setyaningsih dan Setyawan (2014) terdapat hubungan yang bermakna antara persentase luas wilayah atau permukiman dengan kejadian kasus DBD, yang ditunjukkan dengan adanya jumlah kasus yang tinggi pada desa/kelurahan dengan persentase luas wilayah yang tinggi.

3. Angka bebas jentik (ABJ)

ABJ merupakan salah satu ukuran yang dipakai untuk melihat kepadatan vektor penyakit Demam Berdarah Dengue (DBD) yang didasarkan pada House Index (HI), yang dapat memberikan gambaran seberapa besar perkembangan vektor penyakit tersebut pada suatu wilayah. Menurut Setyaningsih dan Setyawan (2014) semakin tinggi kemungkinan perkembangbiakan vektor, maka semakin tinggi pula risiko terjangkitnya penyakit DBD.

4. Peran jumantik (juru pemantau jentik)

Peran jumantik sangat penting dalam sistem kewaspadaan dini DBD karena berfungsi untuk memantau keberadaan serta menghambat perkembangan awal dari vektor penular DBD (Pratamawati, 2012). Keaktifan kader jumantik dalam memantau lingkungannya merupakan langkah penting untuk mencegah meningkatnya

\section{METODE PENELITIAN}

Data yang dipergunakan dalam penelitian ini berupa data sekunder yang diperoleh dari Badan Pusat Statistik (BPS) Kota Denpasar berupa data penduduk pada tahun 2014 dan Dinas Kesehatan Kota Denpasar berupa data kuantitatif mengenai kasus DBD pada tahun 2014. Unit observasi (amatan) yang digunakan dalam penelitian ini adalah 43 desa/kelurahan di Kota Denpasar. Peta pembagian wilayah administrasi dari desa/kelurahan di Kota Denpasar disajikan pada Gambar 3.

Variabel yang digunakan dalam penelitian meliputi variabel dependen dan variabel independen.Varibel dependen (y) adalah kasus DBD. Variabel independen terdiri dari kepadatan penduduk $\left(\mathrm{X}_{1}\right)$, luas wilayah $\left(\mathrm{X}_{2}\right)$, angka bebas jentik $\left(\mathrm{X}_{3}\right)$, dan peran jumantik $\left(\mathrm{X}_{4}\right)$.

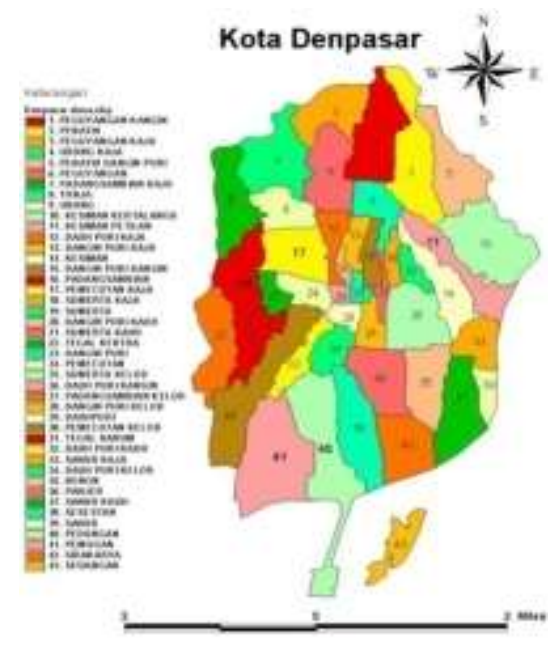

Gambar 3. Peta Pembagian Wilayah Administrasi Kota Denpasar

Metode dan tahapan analisis yang digunakan dalam penelitian ini adalah sebagai berikut:

1. Melakukan eksplorasi data untuk mengetahui pola penyebaran pada setiap variabel dari sudut kewilayahan dengan menggunakan peta tematik.

2. Menentukan matriks pembobot spasial $(W)$ yaitu dengan menggunakan metode persinggungan queen.

3. Uji kebergantungan spasial atau autokorelasi spasial dengan Moran's I dan menggambarkan dengan Moran's 
Scatterplot pada masing- masing variabel.

4. Uji heterogenitas spasial dengan BreuschPagan Test untuk menunjukkan keragaman antardaerah.

5. Melakukan pemodelan SAR dengan tahapan sebagai berikut:
a. Melakukan pendugaan parameter SAR.
b. Melakukan pengujian hipotesis signifikansi parameter dengan uji Wald.
c. Pemilihan model terbaik dengan kriteria AIC (Akaike's Information Criterion) dan $\mathrm{R}^{2}$, model yang terbaik adalah model yang memiliki nilai AIC paling kecil dan dengan nilai $\mathrm{R}^{2}$ yang besar.
d. Menginterpretasikan dan menyimpulkan hasil yang diperoleh.

\section{HASIL DAN PEMBAHASAN}

\subsection{Deskripsi Desa/Kelurahan di Kota Denpasar Berdasarkan Faktor-Faktor yang Memengaruhi Penyebaran Kasus DBD}

Pada penelitian ini angka yang menunjukkan banyaknya kejadian dari setiap variabel dikelompokkan menjadi lima kategori yaitu kategori sangat rendah, rendah, sedang, tinggi, dan sangat tinggi. Hal ini dilakukan agar dapat memudahkan dalam mendeskripsikan setiap variabel penelitian. Berikut ini hasil pemetaan variabel-variabel yang digunakan dalam penelitian.

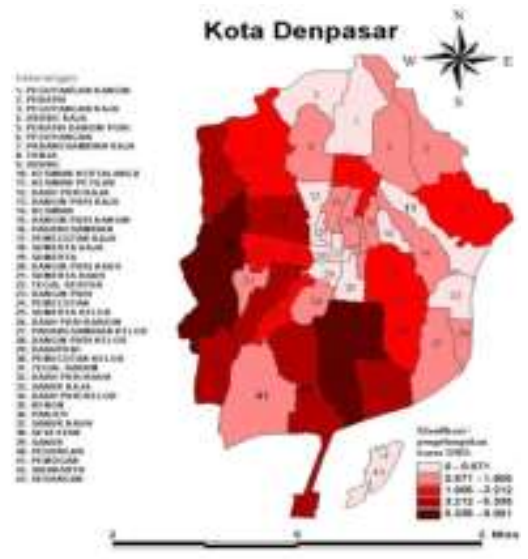

Gambar 4. Peta Penyebaran Persentase Kasus Demam Berdarah Dengue di Kota Denpasar pada Tahun 2014
Berdasarkan Gambar 4, persentase desa/kelurahan yang terdapat kasus DBD terendah di Kota Denpasar pada tahun 2014 sebesar 0\% yaitu Desa Serangan, Kecamatan Denpasar Selatan dan persentase desa/kelurahan yang terdapat kasus DBD tertinggi di Kota Denpasar pada tahun 2014 sebesar 9,091\% yaitu Desa Sesetan, Kecamatan Denpasar Selatan.

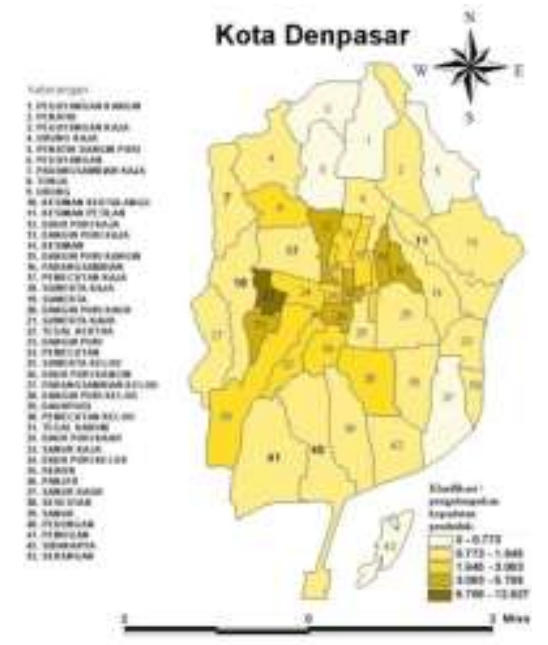

Gambar 5. Peta Penyebaran Persentase Kepadatan Penduduk di Kota Denpasar pada Tahun 2014

Berdasarkan Gambar 5, persentase desa/kelurahan dengan kepadatan penduduk terendah di Kota Denpasar pada tahun 2014 sebesar 0,297\% yaitu Desa Peguyangan Kaja, Kecamatan Denpasar Utara dan persentase desa/kelurahan dengan kepadatan penduduk tertinggi di Kota Denpasar pada tahun 2014 sebesar 12,927\% yaitu Desa Tegal Kertha, Kecamatan Denpasar Barat.

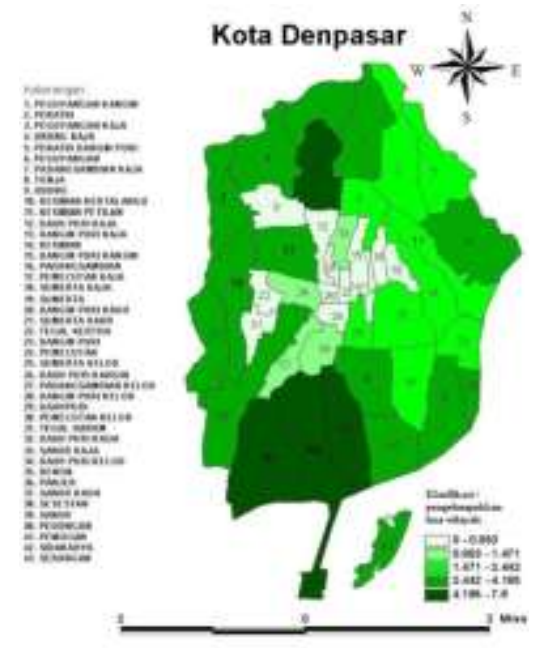

Gambar 6. Peta Penyebaran Persentase Luas Wilayah di Kota Denpasar pada Tahun 2014 
Berdasarkan Gambar 6, persentase desa/kelurahan dengan luas wilayah terendah di Kota Denpasar sebesar 0,274\% yaitu Desa Tegal Kertha, Kecamatan Denpasar Barat dan persentase desa/kelurahan dengan luas wilayah tertinggi di Kota Denpasar sebesar 7,6\% yaitu Desa Pemogan, Kecamatan Denpasar Selatan.

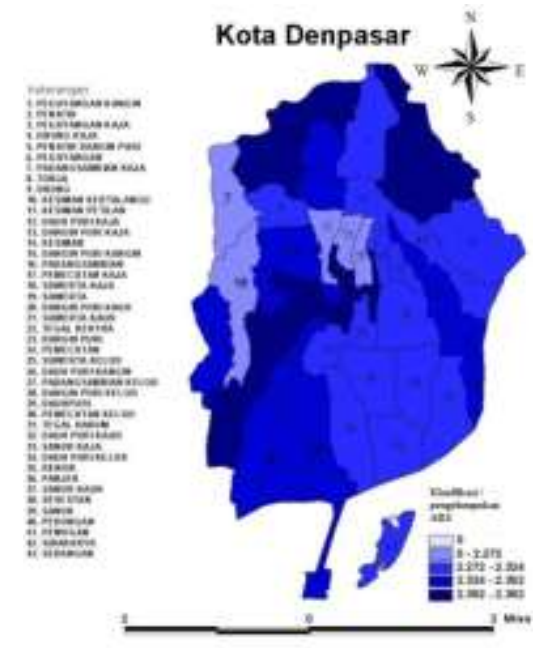

Gambar 7. Peta Penyebaran Persentase Angka Bebas Jentik (ABJ) di Kota Denpasar pada Tahun 2014

Berdasarkan Gambar 7, persentase desa/kelurahan dengan $\mathrm{ABJ}$ terendah di Kota Denpasar sebesar 2,203\% yaitu Desa Dauh Puri Kaja, Kecamatan Denpasar Utara dan persentase desa/kelurahan dengan $\mathrm{ABJ}$ tertinggi di Kota Denpasar sebesar 2,382\% yaitu Desa Penatih Dangin Puri, Kecamatan Denpasar Timur.

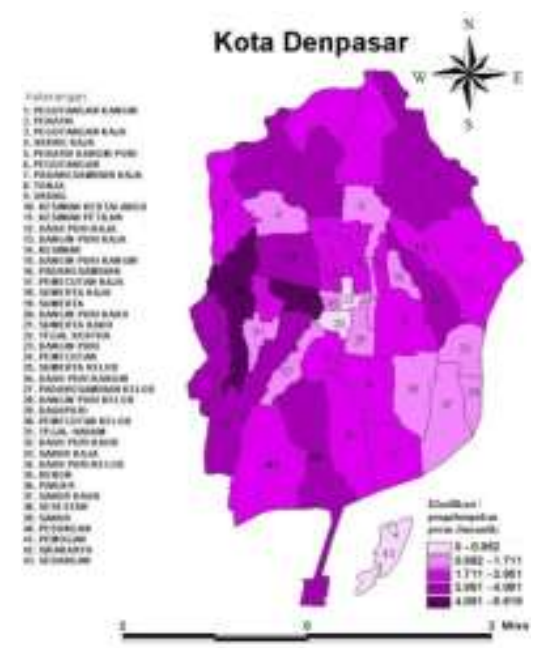

Gambar 8. Peta Penyebaran Persentase Peran (Kunjungan) Jumantik di Kota Denpasar pada Tahun 2014
Berdasarkan Gambar 8, persentase desa/kelurahan dengan kunjungsn jumantik terendah di Kota Denpasar sebesar 0,731\% yaitu Kelurahan Dangin Puri, Kecamatan Denpasar Timur dan persentase desa/kelurahan dengan kunjungan jumantik tertinggi di Kota Denpasar sebesar 6,618\% yaitu Kelurahan Padangsambian, Kecamatan Denpasar Barat.

\subsection{Uji Kebergantungan Spasial}

Uji kebergantungan spasial dilakukan untuk mengidentifikasi apakah ada hubungan antardaerah terhadap masing-masing variabel dengan menggunakan statistik Moran's I. Hipotesis yang digunakan adalah sebagai berikut:

$\mathrm{H}_{0}: \mathrm{I}=0$ (tidak ada kebergantungan spasial antardaerah),

$\mathrm{H}_{1}: \mathrm{I} \neq 0$ (ada kebergantungan spasial antardaerah).

Pengambilan keputusan dilakukan jika $\left|Z_{I}\right|>Z \alpha / 2$ maka tolak $\mathrm{H}_{0}$ yang berarti bahwa ada kebergantungan spasial antardaerah. Hasil pengujian Moran's I disajikan pada Tabel 1 dengan tingkat signifikan 5\%.

Tabel 1. Pengujian Kebergantungan Spasial dengan Moran's I

\begin{tabular}{|c|l|c|c|}
\hline Kode & \multicolumn{1}{|c|}{ Variabel } & Moran's I & $\boldsymbol{Z}_{\boldsymbol{I}}$ \\
\hline $\mathrm{y}$ & $\begin{array}{l}\text { Kasus Demam } \\
\text { Berdarah } \\
\text { Dengue (DBD) }\end{array}$ & 0,403038 & $4,6614^{*}$ \\
\hline $\mathrm{X}_{1}$ & $\begin{array}{l}\text { Kepadatan } \\
\text { penduduk }\end{array}$ & 0,174435 & $2,4654^{*}$ \\
\hline $\mathrm{X}_{2}$ & Luas wilayah & 0,336213 & $4,0361^{*}$ \\
\hline $\mathrm{X}_{3}$ & $\begin{array}{l}\text { Angka bebas } \\
\text { jentik (ABJ) }\end{array}$ & 0,021893 & $2,3444^{*}$ \\
\hline $\mathrm{X}_{4}$ & $\begin{array}{l}\text { Peran jumantik } \\
\text { (juru pemantau } \\
\text { jentik) }\end{array}$ & 0,076833 & $2,6015^{*}$ \\
\hline
\end{tabular}

Sumber: data diolah 2016

Ket: ${ }^{*}$ ) signifikan pada $\alpha=5 \%, Z_{0,025}=1,96$

Berdasarkan Tabel 1 dapat dilihat bahwa nilai $\left|Z_{I}\right|$ pada semua variabel tersebut lebih besar dari nilai $Z \alpha / 2=1,96$. Keputusan yang diambil yaitu tolak $\mathrm{H}_{0}$ yang berarti bahwa ada kebergantungan spasial antardaerah, yaitu pada variabel kasus DBD (y), kepadatan penduduk 
$\left(\mathrm{X}_{1}\right)$, luas wilayah $\left(\mathrm{X}_{2}\right)$, angka bebas jentik $\left(\mathrm{X}_{3}\right)$, dan peran jumantik $\left(\mathrm{X}_{4}\right)$.

\subsection{Uji Heterogenitas Spasial}

Uji heterogenitas spasial digunakan untuk menunjukkan adanya keragaman antardaerah dengan menggunakan Breusch-Pagan Test. Hipotesis yang digunakan adalah sebagai berikut:

$$
\begin{aligned}
\mathrm{H}_{0}: & \sigma_{1}^{2}=\sigma_{2}^{2}=\cdots=\sigma_{n}^{2}=\sigma^{2} \quad \text { (tidak ada } \\
& \text { heterogenitas spasial), } \\
\mathrm{H}_{1}: & \text { minimal ada satu } \sigma_{\mathrm{i}}^{2} \neq \sigma^{2} \quad \text { (ada } \\
\text { heterogenitas spasial) } &
\end{aligned}
$$

Pengambilan keputusan dilakukan jika $\mathrm{BP}>\chi_{\alpha, k}^{2}$ atau $\mathrm{p}$-value $<\alpha$, maka $\mathrm{H}_{0}$ ditolak yang berarti bahwa ada heterogenitas spasial antardaerah. Hasil pengujian heterogenitas spasial disajikan pada Tabel 2 dengan tingkat signifikan 5\%.

Tabel 2. Uji Heterogenitas Spasial BreuschPagan Test

\begin{tabular}{|l|c|l|l|}
\hline \multicolumn{1}{|c|}{ Uji } & DF & Nilai & Prob. \\
\hline $\begin{array}{l}\text { Breusch- } \\
\text { Pagan Test }\end{array}$ & 4 & 23,9723 & 0,00008 \\
\hline
\end{tabular}

Berdasarkan Tabel 2 diperoleh nilai BreuschPagan Test sebesar 23,9723 dan p-value sebesar 0,00008 . P-value yang diperoleh lebih kecil dari $\alpha=0,05$. Keputusan yang diambil adalah tolak $\mathrm{H}_{0}$, yang berarti bahwa adanya heterogenitas spasial antardaerah. Karena pada kasus ini ada kebergantungan spasial antardaerah dan ada heterogenitas spasial antardaerah, sehingga perlu dilakukan pemodelan dengan menggunakan metode spasial.

\subsection{Pemodelan SAR}

Pada pemodelan SAR, pendugaan parameter dilakukan dengan Maximum Likelihood Estimation (MLE). Model umum SAR ditunjukan oleh persamaan sebagai berikut (Anselin, 1988, p.35):

$$
y=\rho W_{1} y+X \beta+\varepsilon .
$$

Pemilihan model terbaik dengan metode semua kemungkinan model menggunakan kriteria AIC dan $\mathrm{R}^{2}$. Model yang terbaik adalah model yang memiliki nilai AIC paling kecil dan nilai $\mathrm{R}^{2}$ yang besar. Dengan cara meregresikan semua variabel independen $\mathrm{X}$ yaitu, $\mathrm{X}_{1}, \mathrm{X}_{2}, \mathrm{X}_{3}$, dan $\mathrm{X}_{4}$ terhadap variabel dependen $\mathrm{y}$, sehingga didapat 15 kombinasi variabel independen. Hasil disajikan pada Tabel 3.

Tabel 3. Nilai AIC dan $\mathrm{R}^{2}$ untuk Pemilihan Model Terbaik

\begin{tabular}{|l|l|l|l|}
\hline No & \multicolumn{1}{|c|}{$\begin{array}{c}\text { Variabel } \\
\text { Independen }\end{array}$} & AIC & $\mathbf{R}^{2}$ \\
\hline 1 & $\mathrm{X}_{1}$ & 173,80 & 0,471 \\
\hline 2 & $\mathrm{X}_{2}$ & 169,82 & 0,497 \\
\hline 3 & $\mathrm{X}_{3}$ & 175,36 & 0,443 \\
\hline 4 & $\mathrm{X}_{4}$ & 167,12 & 0,526 \\
\hline 5 & $\mathrm{X}_{1}$ dan $\mathrm{X}_{2}$ & 171,82 & 0,496 \\
\hline 6 & $\mathrm{X}_{1}$ dan $\mathrm{X}_{3}$ & 175,60 & 0,470 \\
\hline 7 & $\mathrm{X}_{1}$ dan $\mathrm{X}_{4}$ & 168,32 & 0,539 \\
\hline 8 & $\mathrm{X}_{2}$ dan $\mathrm{X}_{3}$ & 171,79 & 0,498 \\
\hline 9 & $\mathrm{X}_{2}$ dan $\mathrm{X}_{4}$ & 166,35 & 0,549 \\
\hline 10 & $\mathrm{X}_{3}$ dan $\mathrm{X}_{4}$ & 168,89 & 0,531 \\
\hline 11 & $\mathrm{X}_{1}, \mathrm{X}_{2}$, dan $\mathrm{X}_{3}$ & 173,78 & 0,497 \\
\hline 12 & $\mathrm{X}_{1}, \mathrm{X}_{2}, \operatorname{dan} \mathrm{X}_{4}$ & 168,34 & 0,548 \\
\hline 13 & $\mathrm{X}_{1}, \mathrm{X}_{3}$, dan $\mathrm{X}_{4}$ & 170,22 & 0,541 \\
\hline 14 & $\mathrm{X}_{2}, \mathrm{X}_{3}$, dan $\mathrm{X}_{4}$ & 167,88 & 0,556 \\
\hline 15 & $\mathrm{X}_{1}, \mathrm{X}_{2}, \mathrm{X}_{3}$, dan $\mathrm{X}_{4}$ & 169,82 & 0,554 \\
\hline
\end{tabular}

Sumber: data diolah 2016

Berdasarkan Tabel 3 didapatkan nilai AIC paling kecil sebesar 166,35 dengan nilai $\mathrm{R}^{2}$ sebesar 0,549 atau $54,9 \%$ yang terdapat pada model nomor 9. Hal ini berarti bahwa model dengan variabel luas wilayah $\left(\mathrm{X}_{2}\right)$ dan peran jumantik $\left(\mathrm{X}_{4}\right)$ mampu menjelaskan variasi dari penyebaran kasus DBD sebesar 54,9\% dan sisanya $45,1 \%$ dijelaskan oleh variabel lain diluar model.

Hasil pendugaan parameter SAR dengan variabel luas wilayah $\left(\mathrm{X}_{2}\right)$ dan peran jumantik $\left(\mathrm{X}_{4}\right)$ disajikan pada Tabel 4.

Tabel 4. Pendugaan Parameter SAR (Variabel $\mathrm{X}_{2}$ dan $\mathrm{X}_{4}$ )

\begin{tabular}{|c|c|l|l|}
\hline Parameter & Dugaan & $\begin{array}{l}\text { Std. } \\
\text { Error }\end{array}$ & Wald \\
\hline$\rho$ & 0,6407 & 0,12330 & $26,9961^{*}$ \\
\hline$\beta_{0}$ & $-0,7196$ & 0,48293 & 2,2222 \\
\hline$\beta_{2}$ & 0,2296 & 0,13566 & $2,8651^{*}$ \\
\hline$\beta_{4}$ & 0,4219 & 0,17551 & $5,7792^{*}$ \\
\hline
\end{tabular}

Sumber: data diolah 2016

Ket: *) signifikan pada $\alpha=10 \%$, dan nilai $\chi_{0.1 ; 1}^{2}=$ 2,706

Berdasarkan pendugaan parameter SAR (Variabel X2 dan X4) yang disajikan pada Tabel 4 , dengan memperhatikan nilai Wald diketahui 
bahwa terdapat kebergantungan lag pada variabel dependen yang ditunjukkan oleh parameter $\rho$, serta variabel X2 dan X4 yang signifikan pada $\alpha=10 \%$. Sehingga diperoleh model terbaik SAR adalah sebagai berikut:

$$
\begin{array}{r}
\hat{y}_{i}=0,6407 \sum_{j=1, i \neq j}^{n} w_{i j} y_{j}+ \\
0,2296 X_{2 i}+0,4219 X_{4 i} .
\end{array}
$$

Setiap desa/kelurahan memiliki model SAR yang berbeda-beda, hal ini bergantung pada matriks pembobot spasial $\left(\mathrm{W}_{1}\right)$ dari desa/kelurahan yang berdekatan dengan desa/kelurahan yang diamati. Sebagai contoh Desa Peguyangan Kangin yang mempunyai model SAR sebagai berikut:

$$
\begin{aligned}
& \hat{y}_{\text {Peguyangan_Kangin }}=0,6407 y_{\text {Penatih }}+ \\
& 0,6407 y_{\text {Peguyangan_Kaja }}+ \\
& 0,6407 y_{\text {Peguyangan }}+0,6407 y_{\text {Tonja }}+ \\
& 0,2296 X_{2 \text { Peguyangan_Kangin }}+ \\
& 0,4219 X_{4 \text { Peguyangan_Kangin }} .
\end{aligned}
$$

\section{KESIMPULAN DAN SARAN}

Berdasarkan hasil dan pembahasan didapatkan kesimpulan sebagai berikut:

1. Pada penyebaran kasus DBD di Kota Denpasar pada tahun 2014, terdapat kebergantungan spasial antardaerah dan adanya heterogenitas spasial antardaerah, sehingga menggunakan metode regresi spasial yaitu model SAR. Model SAR yang terbaik dengan nilai AIC paling kecil sebesar 166,35 dengan nilai $\mathrm{R}^{2}$ sebesar 0,549 atau $54,9 \%$. Model SAR yang terbentuk untuk memodelkan penyebaran kasus DBD di Kota Denpasar pada tahun 2014 adalah sebagai berikut:

$$
\begin{gathered}
\hat{y}_{i}=0,6407 \sum_{\substack{j=1, i \neq j \\
+0,4219}}^{n} w_{i j} y_{j}+0,2296 X_{2 i} \\
+0 .
\end{gathered}
$$

2. Faktor yang berpengaruh terhadap penyebaran kasus DBD di Kota Denpasar pada tahun 2014 adalah faktor ketetanggaan antardaerah, persentase luas wilayah pada setiap desa/kelurahan dan persentase peran (kunjungan) jumantik di setiap desa/kelurahan di Kota Denpasar.
Saran yang dapat diberikan untuk penelitian selanjutnya adalah agar lebih memperhatikan pemilihan faktor-faktor yang memengaruhi penyebaran kasus DBD lainnya, mempertimbangkan faktor non linear, dan menggunakan matriks pembobot spasial yang berbeda, salah satu jenis pembobot tersebut adalah dengan menggunakan matriks pembobot spasial berdasarkan Distance Band, untuk mendapatkan model regresi yang lebih baik

\section{DAFTAR PUSTAKA}

A'yunin, Q., \& Sutijo, B. 2011. Pemodelan Gizi Buruk Pada Balita di Kota Surabaya dengan Spatial Autoregressive Model (SAR)http://digilib.its.ac.id/public/ITSUndergraduate-16316-1309105010paperpdf.pdfDiakses pada tanggal 15 Maret 2016

Anselin, L. 1988. Spatial Econometrics : Methods and Models. The Netherlands: Kluwer Academic Publishers.

BPS (Badan Pusat Statistik) Kota Denpasar. 2015. Denpasar Dalam Angka 2015. Denpasar: BPS Kota Denpasar.

Dinas Kesehatan Kota Denpasar. 2015. Profil Kesehatan Kota Denpasar Tahun 2014. Denpasar: Dinas Kesehatan Kota Denpasar.

Dinas Kesehatan Provinsi Bali. 2015. Profil Kesehatan Provinsi Bali Tahun 2014. Denpasar: Dinas Kesehatan Provinsi Bali.

Kementerian Kesehatan RI. 2015. Profil Kesehatan Indonesia Tahun 2014. Jakarta: Kementerian Kesehatan RI.

Lee, J., \& Wong, D. W. 2001. Statistical Analysis with Arcview GIS. New York: John Wiley and Sons, Inc.

LeSage, J. P. 1999. The Theory and Practice of Spatial Econometrics. Department of Economics: University of Toledo.

Pratamawati, D. A. 2012. Peran Juru Pantau jentik dalam Sistem Kewaspadaan Dini Demam Berdarah Dengue di Indonesia. Jurnal Kesehatan Masyarakat Nasional, Volume 6, No 6.

Setyaningsih, W., \& Setyawan, D. A. 2014. Pemodelan Sistem Informasi Geografis (SIG) pada Distribusi Penyakit Demam Berdarah Dengue (DBD) di Kecamatan Karangmalang Kabupaten Sragen. Jurnal Terpadu Ilmu Kesehatan, Vol. 3, No 2, hlm 106-214. 